\title{
EARLY CENOZOIC GLOBAL PLATE REORGANIZATION
}

\author{
PETER A. RONA and EVAN S. RICHARDSON * \\ National Oceanic and Atmospheric Administration, Atlantic Oceanographic and Meteorological Laboratories, \\ Miami, FL 33149 (U.S.A.)
}

Received November 9, 1977

Revised version received February 28, 1978

\begin{abstract}
Synthesis of regional plate movements reveals a major reorganization of global plate motion from Mesozoic to Cenozoic patterns that occurred primarily during the Eocene epoch (53.5 to 37.5 m.y. B.P.). The reorganization involved reorientation of relative plate motions with large N-S components into large $\mathrm{E}-\mathrm{W}$ components, continuation of pre-existing E-W sea floor spreading, initiation of new E-W spreading, deceleration of spreading rates, and obduction of ophiolites. The reorganization is attributed to increase in resistance imposed on the global plate system by increase in length of E-W-trending collisional plate boundaries from 2500 to $28,500 \mathrm{~km}$ during the interval 55 to $40 \mathrm{~m} . \mathrm{y}$. B.P., forcing the system to reorient along lines of less resistance. The pattern of global plate motion resulting from the reorganization is constrained by the resistance imposed by $19,000 \mathrm{~km}$ of collisional plate boundaries.
\end{abstract}

\section{Introduction}

The extensive literature treating regional plate motions of Mesozoic and Cenozoic age provides a basis for determining global patterns of plate motions and evaluating the degree of interaction between plates. The Early Mesozoic beginning of the breakup and dispersion of Pangaea is a recognized time of global plate reorganization [1]. Synthesis of regional information on sea floor spreading (Table 1), orogenic activity (Table 1), and obduction of ophiolites (Table 2 ), evidences a global plate reorganization from Mesozoic to Cenozoic patterns of plate motion during the interval between 55 and 40 m.y. B.P. The interval includes portions of the Paleocene ( 65 to 53.5 m.y. B.P.) and Eocene (53.5 to 37.5 m.y. B.P.), employing revised time scales for the Cretaceous [2], the Cenozoic [3], and for magnetic polarity reversals [4].

\footnotetext{
* Also University of Miami, Rosenstiel School of Marine and Atmospheric Sciences, Miami, Florida 33149, U.S.A. Present address: Deep Sea Exploration, Phillips Petroleum Company, Bartlesville, Oklahoma 74004, U.S.A.
}

\section{Regional plate reorganization}

Consideration of regional plate motions follows a global circuit of plate boundaries from the Indian Ocean, to the Pacific, Arctic, Atlantic, Caribbean, Mediterranean, and Red Sea. Pertinent information and references are summarized in Tables 1 and 2, so the text will simply outline major events with reference to the tables and to Figs. 1 and 2.

Plate reorganization in the Indian Ocean region involved reorientation of the oceanic ridge system from a predominantly E-W trend that had prevailed since about 100 m.y. B.P., to a NW-SE trend beginning between 53 and 50 m.y. B.P. (Table 1, Fig. 1). The ridge orientation was nearly synchronous with the inferred time of initial collision and decrease in rate of relative motion between India and Eurasia ( 55 to 40 m.y. B.P.), termination of ophiolite obduction at the Indus suture zone ( 49 m.y. B.P.; Table 2), and marked decrease in rate of sea floor spreading (approx. imately $50 \%$; 53 to 40 m.y. B.P.; Table 1). A change in pattern of plate motion occurred south of Australia. Sea floor spreading about a nearly N-S-trending ridge system ended in the Tasman Sea (59 to 56 m.y. B.P.), 
TABLE 1

Regional plate motions (see Figs. 1, 2)

\begin{tabular}{|c|c|c|c|}
\hline Region & Event & Time (evidence) & Reference \\
\hline Indian Ocean & $\begin{array}{l}\text { Beginning of continental collision between } \\
\text { India and Eurasia }\end{array}$ & $\begin{array}{l}55 \text { to } 40 \text { m.y. B.P. (structural and stratigraphic } \\
\text { relations) }\end{array}$ & {$[5-9]$} \\
\hline Indian Ocean & Decrease in sea floor spreading rates between & 53 to $40 \mathrm{~m} . y$. B.P. (magnetic anomalies 21 & {$[10-12]$} \\
\hline
\end{tabular}

India and Antarctica-Australia by a factor of approximately 2 from $>8$ to $<4 \mathrm{~cm} / \mathrm{yr}$ (half rate)

Indian Ocean Subduction of nearly E-W-trending oceanic ridge between Australia and Eurasia at convergent plate boundary along the southern margin of Eurasia

Indian Ocean Reorientation of oceanic ridge system from nearly E-W to NW-SE with concommitant change in sea floor spreading direction from nearly N-S to NE-SW.

Indian Ocean Ending of sea floor spreading with large E-W component in Tasman Sea

Indian Ocean Beginning of sea floor spreading with large $\mathrm{N}-\mathrm{S}$ component between Australia-Broken Ridge and Antarctica-Kerguelen Plateau

Indian Ocean Decrease in rate of relative motion between India and Eurasia plates by a factor of approximately 2 from about 10 to $5 \mathrm{~cm} / \mathrm{yr}$

South Pacific Decrease in rate of sea floor spreading by a factor of approximately 2 from about 5 to $2.3 \mathrm{~cm} / \mathrm{yr}$

South Pacific Collision between Australian shield and New Guinea island arc

South Pacific Beginning of sea floor spreading west of Scotia Sea

South Pacific Rifting of South America from Antarctic peninsula

North Pacific Laramide orogeny predominantly E-W compressive deformation and plutonism in western North America and northwestern South America

North Pacific Change in direction of sea floor spreading from ENE-WSW to E-W evidenced by Zed pattern of magnetic anomalies and trends of fracture zones

North Pacific Beginning of subduction along Philippine, Bonin, Marianas, Yap, Palau, and Tonga trench-arc systems

North Pacific Change in direction of plate motion from NNW to WNW with respect to Hawaiian hot spot evidenced by Emperor SeamountHawaiian Ridge bend

Arctic Beginning of sea floor spreading in an E-W direction about the Gakkel Ridge resulting in opening of the Eurasian Basin

53 to 32 m.y. B.P. (magnetic anomalies 11 and 22)

53 to 50 m.y. B.P. (magnetic anomalies 21 and 22)

59 to 56 m.y. B.P. (after magnetic anomaly 25)

53 to 50 m.y. B.P. (magnetic anomalies 21 and 22)

50 to 38 m.y. B.P. (magnetic anomalies)

56 m.y. B.P. (magnetic anomaly 24)

49 to 43 m.y. B.P. (Middle Eocene; structural and stratigraphic relations)

54 to 30 m.y. B.P. (magnetic anomalies)

54 to 30 m.y. B.P. (magnetic anomalies)

80 to 40 m.y. B.P.

55 to 50 m.y. B.P. (magnetic anomalies 21 to 23 )

Shortly after 45 m.y. B.P. (maximum ages and trends of associated island arcs)

43 to 41 m.y. B.P. (radiometric dating)

[26]

63 m.y. B.P. (magnetic anomalies) 
TABLE 1 (continued)

\begin{tabular}{|c|c|c|c|}
\hline Region & Event & Time (evidence) & Reference \\
\hline North Atlantic & $\begin{array}{l}\text { Duration of sea floor spreading in the Nor- } \\
\text { wegian Basin }\end{array}$ & 56 to 42 m.y. B.P. (magnetic anomalies) & [29] \\
\hline North Atlantic & $\begin{array}{l}\text { Beginning of spreading at Iceland-Jan } \\
\text { Mayen Ridge }\end{array}$ & 42 m.y. B.P. (magnetic anomalies) & [29] \\
\hline North Atlantic & $\begin{array}{l}\text { Duration of second episode of sea floor } \\
\text { spreading in the Labrador Sea }\end{array}$ & $\begin{array}{l}56 \text { to } 44 \text { m.y. B.P. (magnetic anomalies } 19 \\
\text { to } 24 \text { ) }\end{array}$ & {$[30,31]$} \\
\hline North Atlantic & Beginning of spreading on Reykjanes Ridge & 56 m.y. B.P. (magnetic anomaly 24 ) & {$[32,33]$} \\
\hline North Atlantic & $\begin{array}{l}\text { Change in spreading direction on Reykjanes } \\
\text { Ridge from indeterminate to } \mathrm{E}-\mathrm{W}\end{array}$ & 40 m.y. B.P. (magnetic anomalies) & {$[32,33]$} \\
\hline North Atlantic & $\begin{array}{l}\text { Decrease in rate of sea floor spreading north } \\
\text { of the Azores-Gibraltar lineament by a factor } \\
\text { of approximately } 2 \text { from about } 2.5 \text { to } 1.0 \\
\mathrm{~cm} / \mathrm{yr}^{\mathrm{I}}\end{array}$ & $\begin{array}{l}59 \text { to } 50 \text { m.y. B.P. (magnetic anomalies } 21 \\
\text { to } 25 \text { ) }\end{array}$ & {$[27]$} \\
\hline North Atlantic & $\begin{array}{l}\text { Decrease in rate of sea floor spreading south } \\
\text { of the Azores-Gibraltar lineament by a factor } \\
\text { of approximately } 1.5 \text { from about } 1.7 \text { to } 1.2 \\
\mathrm{~cm} / \mathrm{yr}\end{array}$ & $\begin{array}{l}59 \text { to } 50 \text { m.y. B.P. (magnetic anomalies } \\
21 \text { to } 25 \text { ) }\end{array}$ & {$[27,34]$} \\
\hline North Atlantic & $\begin{array}{l}\text { Change in relative direction of spreading from } \\
\text { nearly E-W to WNW-ESE evidenced by bend } \\
\text { in Kane fracture zone }\end{array}$ & $\begin{array}{l}59 \text { to } 50 \text { m.y. B.P. (magnetic anomalies } 21 \\
\text { to } 25 \text { ) }\end{array}$ & [35] \\
\hline South Atlantic & $\begin{array}{l}\text { No apparent changes in sea floor spreading } \\
\text { rate and direction based on limited data }\end{array}$ & $\begin{array}{l}72 \text { to } 0 \text { m.y. B.P. (axial magnetic anomaly } \\
\text { to anomaly } 31 \text { ) }\end{array}$ & {$[36-38]$} \\
\hline Caribbean & $\begin{array}{l}\text { Separation of Caribbean plate from Pacific } \\
\text { plate as a consequence of southward extension } \\
\text { of the Middle Americas Trench }\end{array}$ & $\begin{array}{l}54 \text { to } 38 \mathrm{~m} . \mathrm{y} \text {. B.P. (Eocene age of earliest } \\
\text { volcanics in Central America) }\end{array}$ & [39] \\
\hline Caribbean & $\begin{array}{l}\text { Jump of subduction zone from Aves Ridge } \\
\text { to Lesser Antilles island arc }\end{array}$ & $\begin{array}{l}54 \text { m.y. B.P. ( } 60 \text { m.y. B.P. radiogenic date of } \\
\text { granodiorite from Aves Ridge; } 54 \text { m.y. B.P. } \\
\text { initiation of volcanism in Lesser Antilles) }\end{array}$ & {$[40,39]$} \\
\hline Caribbean & $\begin{array}{l}\text { Collision of Bahama Banks with Greater } \\
\text { Antilles (Cuba) }\end{array}$ & $\begin{array}{l}\text { Post- } 70 \text { to } 43 \text { m.y. B.P. (Late Cretaceous to } \\
\text { Middle Eocene based on structural relations) }\end{array}$ & {$[41,42]$} \\
\hline Caribbean & End of N-S subduction at Puerto Rico & $\begin{array}{l}49 \text { to } 43 \mathrm{~m} . \mathrm{y} . \text { B.P. (Middle Eocene radiogenic } \\
\text { age of youngest volcanic rocks present) }\end{array}$ & {$[42]$} \\
\hline Caribbean & Beginning of present Puerto Rico Trench & $\begin{array}{l}\text { Post }-43 \text { m.y. B.P. (post-Middle Eocene based } \\
\text { on structural and stratigraphic relations) }\end{array}$ & {$[43-45]$} \\
\hline Caribbean & End of N-S subduction at Cuba & $\begin{array}{l}49 \text { to } 43 \text { m.y. B.P. (Middle to Late Eocene } \\
\text { based on structural relations) }\end{array}$ & {$[41,44]$} \\
\hline Caribbean & End of N-S subduction at Hispaniola & $\begin{array}{l}\text { Prior to } 43 \text { m.y. B.P. (pre-Late Eocene based } \\
\text { on stratigraphic relations) }\end{array}$ & {$[46]$} \\
\hline Caribbean & $\begin{array}{l}\text { General change of plate motion from N-S } \\
\text { compression to E-W strike slip }\end{array}$ & $\begin{array}{l}54 \text { to } 38 \text { m.y. B.P. (Eocene based on structural } \\
\text { relations at northern and southern boundaries } \\
\text { of Caribbean plate) }\end{array}$ & [39] \\
\hline Caribbean & $\begin{array}{l}\text { Beginning of sea floor spreading in present } \\
\text { Cayman Trough }\end{array}$ & $\begin{array}{l}49 \text { to } 43 \text { m.y. B.P. (Middle Eocene based on } \\
\text { estimated spreading and sedimentation rates) }\end{array}$ & {$[47,48]$} \\
\hline Mediterranean & $\begin{array}{l}\text { Right lateral E-W strike slip motion along } \\
\text { Tethys }\end{array}$ & $\begin{array}{l}80 \text { to } 53 \text { m.y. B.P. (deduced from relative plate } \\
\text { motions in the North Atlantic) }\end{array}$ & [49] \\
\hline Mediterranean & $\begin{array}{l}\text { Change to N-S collision, compression and } \\
\text { subduction along Tethys }\end{array}$ & $\begin{array}{l}53 \mathrm{~m} . \mathrm{y} . \text { B.P. (deduced from relative plate } \\
\text { motions in the North Atlantic) }\end{array}$ & {$[49]$} \\
\hline
\end{tabular}


TABLE 1 (continued)

\begin{tabular}{|c|c|c|c|}
\hline Region & Event & Time (evidence) & Reference \\
\hline Mediterranean & Collision of Iberian peninsula with Eurasia & $\begin{array}{l}54 \text { to } 38 \text { m.y. B.P. (Eocene based on structural } \\
\text { relations) }\end{array}$ & {$[50]$} \\
\hline Mediterranean & $\begin{array}{l}\text { Beginning of deformation of Betic moun- } \\
\text { tains in southern Spain }\end{array}$ & $\begin{array}{l}49 \text { to } 43 \text { m.y. B.P. (Middle Eocene based on } \\
\text { structural relations) }\end{array}$ & {$[49]$} \\
\hline Mediterranean & $\begin{array}{l}\text { Possible reversal of subduction polarity } \\
\text { in Swiss Alps }\end{array}$ & $\begin{array}{l}49 \text { to } 43 \text { m.y. B.P. (Middle Eocene based on } \\
\text { structural relations) }\end{array}$ & {$[51]$} \\
\hline Mediterranean & $\begin{array}{l}\text { Meso-Alpine orogeny involving main move- } \\
\text { ments of Penninic and Austroalpine nappes } \\
\text { in Swiss Alps }\end{array}$ & $\begin{array}{l}43 \text { to } 38 \mathrm{~m} . \mathrm{y} . \text { B.P. (Late Eocene to Early Oli- } \\
\text { gocene based on structural relations) }\end{array}$ & {$[52]$} \\
\hline Mediterranean & Subduction in Tellian Atlas and Sicilides & $\begin{array}{l}54 \text { to } 38 \text { m.y. B.P. (Eocene based on active } \\
\text { flysch sedimentation) }\end{array}$ & {$[49]$} \\
\hline Mediterranean & $\begin{array}{l}\text { End of subduction in eastern Alps as a con- } \\
\text { sequence of continental collision }\end{array}$ & $\begin{array}{l}45 \text { to } 42 \text { m.y. B.P. (structural and stratigraphic } \\
\text { relations) }\end{array}$ & {$[53]$} \\
\hline Mediterranean & Orogeny in High Atlas and Saharan Atlas & $\begin{array}{l}43 \text { to } 30 \mathrm{~m} . y \text {. B.P. (post-Middle Eocene and } \\
\text { pre-Middle Oligocene based on structural and } \\
\text { stratigraphic relations) }\end{array}$ & {$[54,55]$} \\
\hline Red Sea & $\begin{array}{l}\text { Beginning of sea floor spreading with large } \\
\text { E-W component }\end{array}$ & 38 m.y. B.P. (magnetic anomalies) & {$[56]$} \\
\hline
\end{tabular}

TABLE 2

Early Cenozoic ophiolites (see Figs. 1, 2)

\begin{tabular}{|c|c|c|c|}
\hline Region & Location & Age of obduction (evidence) & Reference \\
\hline Indian Ocean & $\begin{array}{l}\text { Indus suture zone of the } \\
\text { Himalayas }\end{array}$ & $\begin{array}{l}100 \text { to } 49 \text { m.y. B.P. (Late Cretaceous through Early Eocene } \\
\text { based on Eocene age of youngest ophiolites and of granites } \\
\text { that intrude ophiolites) }\end{array}$ & {$[6]$} \\
\hline Indian Ocean & Andaman Islands & $\begin{array}{l}53 \text { to } 43 \mathrm{~m} . \mathrm{y} \text {. B.P. (Early and Middle Eocene based on over- } \\
\text { lying Miocene shale and other stratigraphic evidence) }\end{array}$ & {$[16]$} \\
\hline South Pacific & $\begin{array}{l}\text { East Papua and West Irian, } \\
\text { New Guinea }\end{array}$ & $\begin{array}{l}52 \text { m.y. B.P. (Early Eocene based on tadiometric dating of } \\
\text { metamorphic and intrusive rocks in the ophiolites }\end{array}$ & {$[57]$} \\
\hline South Pacific & New Caledonia & $\begin{array}{l}43 \text { to } 37 \text { m.y. B.P. (Late Eocene based on Lower and Middle } \\
\text { Eocene sediments underlying ophiolite and ophiolite debris } \\
\text { in Upper Eocene flysch) }\end{array}$ & {$[58,59]$} \\
\hline North Pacific & Philippine Islands & 54 to 37 m.y. B.P. (Eocene based on structural relations) & {$[60]$} \\
\hline North Pacific & $\begin{array}{l}\text { Knight Island, southern } \\
\text { Alaska }\end{array}$ & $\begin{array}{l}65 \text { to } 52 \text { m.y. B.P. (Paleocene through Early Eocene age of } \\
\text { intrusion of ophiolitic type rocks and trench-type flysch } \\
\text { sediments) }\end{array}$ & {$[61]$} \\
\hline North Pacific & $\begin{array}{l}\text { Coastal Cordillera of Vene- } \\
\text { zuela and Western Cordillera } \\
\text { of Colombia }\end{array}$ & $\begin{array}{l}54 \text { to } 30 \mathrm{~m} . \mathrm{y} . \text { B.P. (Eocene and Early Oligocene based on } \\
\text { structural relations) }\end{array}$ & {$[62]$} \\
\hline Arctic & No Eocene ophiolites known & & \\
\hline North Atlantic & No Eocene ophiolites known & & \\
\hline South Atlantic & No Eocene ophiolites known & & \\
\hline Mediterranean & Eastern Alps & $\begin{array}{l}100 \text { to } 45 \mathrm{~m} . \mathrm{y} \text {. B.P. (Late Cretaceous to Late Eocene based } \\
\text { on structural relations and radiogenic dates) }\end{array}$ & {$[53,63]$} \\
\hline Mediterranean & Corsica & 54 to 37 m.y. B.P. (Eocene) & [49] \\
\hline
\end{tabular}


and spreading about a nearly E-W-trending ridge system began between Australia-Broken Ridge and Antarctica-Kerguelen Plateau (53 to 50 m.y.; Table 1; Fig. 1).

In the South Pacific region the largest known change in rate of sea floor spreading during the past $72 \mathrm{~m}$.y. is inferred to have occurred about 56 m.y. B.P. (Table 1); no major changes of direction are known to have accompanied the spreading rate change at that time. Ophiolites were obducted in New Guinea (52 m.y. B.P.: Table 2: Fig. 2) and New Caledonia (43 to 37 m.y. B.P.), possibly related to collision of those islands with the Australian shield (49 to 43 m.y. B.P.; Table 1). Events in the southeastern Pacific (Table 1) require further documentation.

Structures inferred to have been transform faults during the late Mesozoic along the western margin of the South Pacific and North Pacific became subduction zones shortly after 45 m.y. B.P. (Table 1; Fig. 2). This conversion from transform motion to subduction may be related to the changes in direction of sea floor spreading from large N-S to large E.W components in the Indian Ocean as already noted (53 to 50 m.y. B.P.), and in the North Pacific evidenced by trends of magnetic anomalies and fracture zones (55 to 50 m.y. B.P.; Table 1), and the Emperor Seamount-Hawaiian Ridge bend (43 to 41 m.y. B.P.; Table 1; Fig. 2). The large E-W component of relative motion was manifested at the eastern margin of the North Pacific by continued $\mathrm{E}-\mathrm{W}$ compressive deformation of the Laramide orogeny ( 80 to 40 m.y. B.P.; Table 1), and in the South Pacific by continued subduction along the western margin of South America (Fig. 2).

In the Arctic region E.W sea floor spreading about the Gakkel Ridge, a northward continuation of the Mid-Atlantic Ridge, began about 63 m.y. B.P. (Table 1 ; Fig. 1). Several prominent changes in sea floor spreading occurred in the northern North Atlantic during the interval between 56 and 42 m.y. B.P. involving shifts in spreading about essentially N-S ridges (Table 1; Fig. 1). In the North Atlantic marked decreases in rate of sea floor spreading (approximately $50 \%$ ) about the Mid-Atlantic Ridge occurred both north and south of the Azores-Gibraltar lineament within the interval 59 to 50 m.y. B.P. (Table 1; Fig. 1). A change in relative direction of spreading from nearly E-W to WNW-ESE documented at the Kane fracture zone occurred synchronously with the change in spreading rate (Table 1; Fig. 1). Limited data from the South Atlantic region do not reveal any apparent major changes in spreading rate or direction in the Early Cenozoic.

The Caribbean region underwent plate reorganization during the Eocene. A pattern of N-S compression and subduction that had prevailed since about 110 m.y. B.P. at the northern and southern boundaries of the Caribbean plate changed to predominant E-W strike slip motion from 54 to 38 m.y. B.P. (Table 1; Fig. 2). The termination of N-S subduction at the northern margin of the Greater Antilles between 49 and 43 m.y. B.P., and the initiation of the present Puerto Rico (43 m.y. B.P.) and Cayman trenches (49 to 43 m.y. B.P.) manifest this change. The change may not have been synchronous or complete along the southern boundary of the Caribbean as evidenced, for example, by the obduction of ophiolites at the northern margin of South America as recently as 30 m.y. B.P. (Table 2; Fig. 1).

A change in pattern of plate motion in the Mediterranean region was nearly antithetic to that described in the Caribbean region. Right lateral E-W strike slip motion, inferred to have prevailed along the Tethys between 80 and 53 m.y. B.P., changed to N-S compression and subduction at about 53 m.y. B.P. with associated orogenic episodes and ophiolite obduction at the bounding plate margins (Table 1 ; Fig. 1). In the Red Sea, the final segment in the global circuit of plate boundaries, sea floor spreading with a large E-W component, began about 38 m.y. B.P. (Table 1; Fig. 1).

\section{Global plate reorganization}

Consideration of the regional changes in plate motion (Table 1; Figs. 1,2) reveals patterns of Early Cenozoic plate reorganization which occurred primarily during the Eocene ( 53.5 to 37.5 m.y. B.P.), as follows:

(1) Major reorientation of those relative plate motions with large N-S components to large E-W components. This pattern is exhibited by changes in the direction of spreading in the Indian Ocean (53 to 50 m.y. B.P.) and the North Pacific Ocean ( 55 to 50 m.y. B.P.), as well as by change in the direction of motion of the North Pacific sea floor with respect 

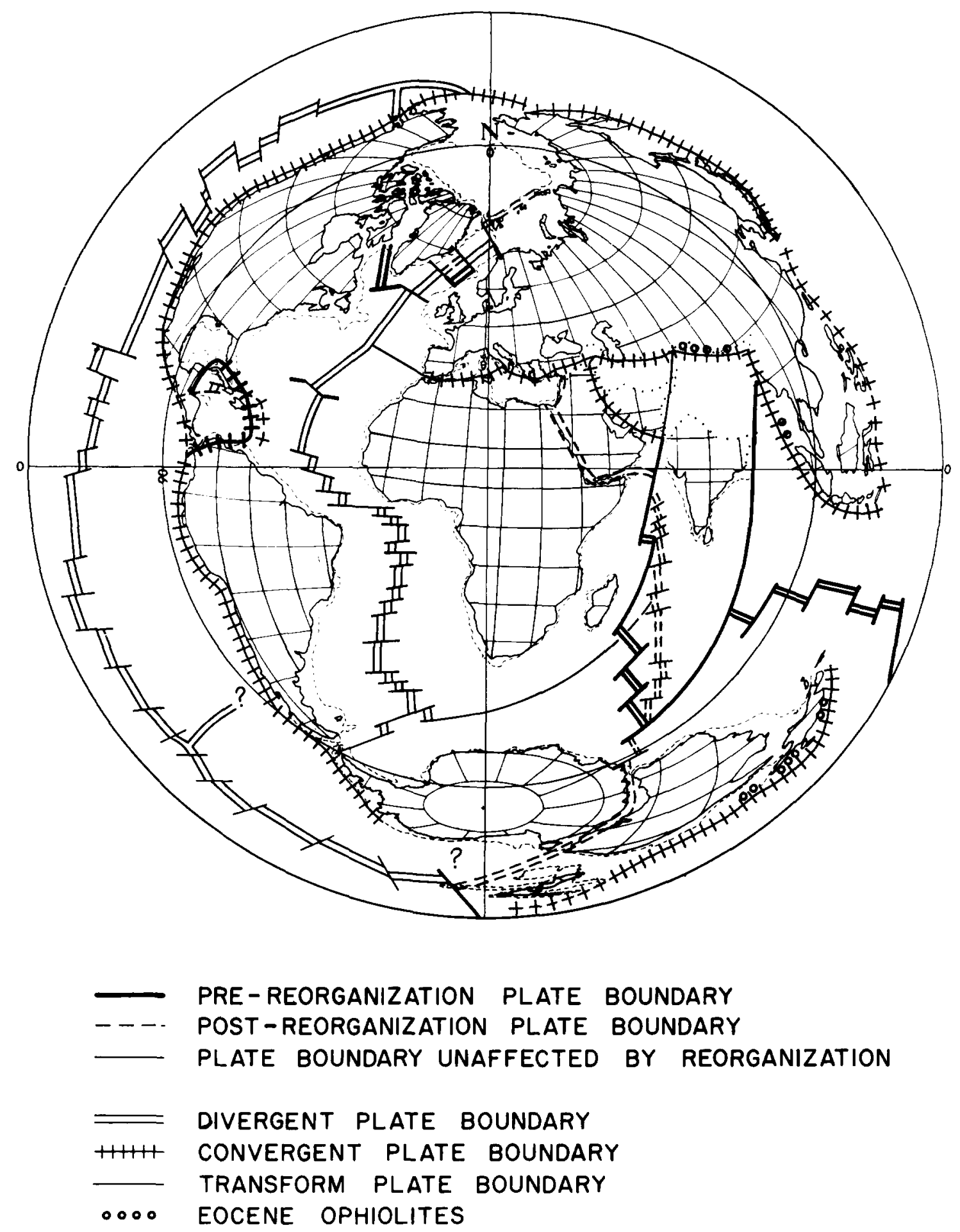

Fig. 1. Plate boundaries before and after Early Cenozoic plate reorganization plotted on Lambert equal area projection showing Eocene $(50 \pm 5$ m.y. B.P.) distribution of continents [65]. Front view. 

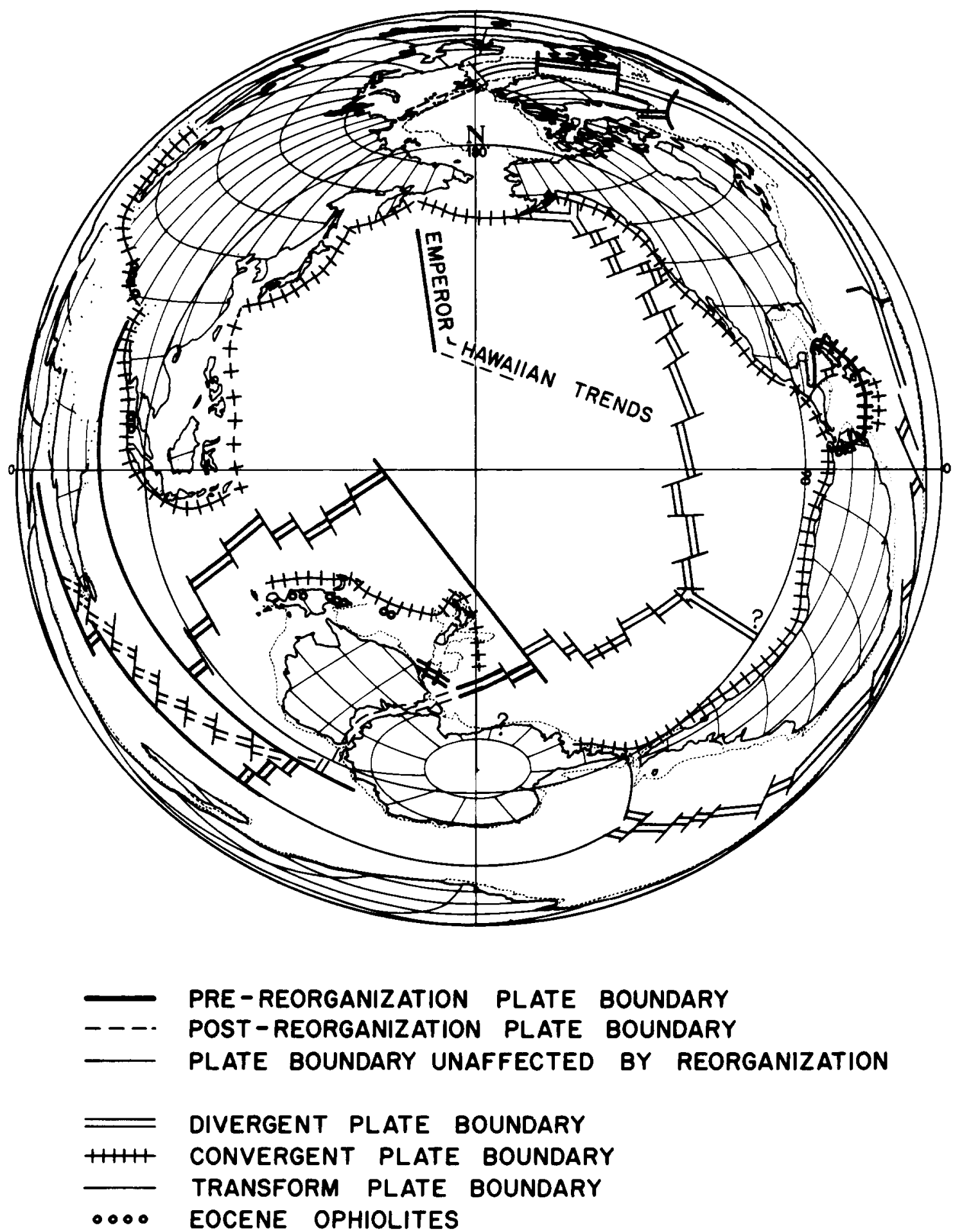

Fig. 2. Plate boundaries before and after Early Cenozoic plate reorganization plotted on Lambert equal area projection showing Eocene ( $50 \pm 5 \mathrm{~m} . \mathrm{y}$. B.P.) distribution of continents [65]. Back view. 
to the Hawaiian hot spot (43 to 41 m.y. B.P.).

(2) Continuation with only minor reorientation of these plate motions with large E-W components and initiation of new E-W relative plate motions. This pattern is exhibited by continued E-W sea floor spreading about the Mid-Atlantic Ridge in the North Atlantic and South Atlantic, and by the initiation of predominantly E-W spreading about centers in the Arctic Ocean (63 m.y. B.P.), the northern North Atlantic Ocean (56 to 42 m.y. B.P.), and the Red Sea (38 m.y. B.P.).

(3) Decrease in rate of sea floor spreading affecting both regions of major and minor reorientation of sea floor spreading (patterns 1 and 2). Such decreases in spreading rate occurred in the Indian Ocean ( 53 to 40 m.y. B.P.), the South Pacific (56 m.y. B.P.), and the North Atlantic (59 to 50 m.y. B.P.), concurrently with reorientation of spreading direction.

(4) Change in nature of motion at certain plate boundaries between convergence with compression and strike slip. Such change occurred antithetically in two different regions within similar latitudes. In the Caribbean region N-S compression and subduction at E-W-trending convergent plate boundaries changed to predominant E-W strike slip motion (54 to 38 m.y. B.P.). In the Mediterranean region E-Wtrending strike slip motion changed to N-S compression at a convergent plate boundary (53 m.y. B.P.).

(5) Conversion of certain transform plate boundaries to convergent plate boundaries as a consequence of major reorientation of plate motions. During the change in direction of sea floor spreading from large N-S to large E-W components in the Indian Ocean and North Pacific regions (55 to 41 m.y. B.P.), inferred pre-existing $\mathrm{N}$-S-trending transform faults along the western margin of the Pacific became subduction zones.

(6) Sequential extinction of one spreading center and initiation of another spreading center with major reorientation of spreading. Such a change occurred within the same region within similar latitudes. The end of E-W spreading in the Tasman Sea ( 59 to 56 m.y. B.P.) was followed by the beginning of N-S spreading south of Australia (53 to 50 m.y. B.P.).

(7) Obduction of ophiolites at certain convergent plate boundaries involved in reorganization of plate motion in the Indian Ocean (100 to 43 m.y. B.P.), the South Pacific (52 to 37 m.y. B.P), the North
Pacific (65 to 30 m.y. B.P.), and the Mediterranean (100 to 37 m.y. B.P.) regions (Table 3). Obduction of ophiolites may be a prime indicator of plate reorganization.

\section{Global plate interaction}

The nature of the plate interactions which produced the observed patterns of Early Cenozoic global plate reorganization may be deduced from assessment of global plate boundaries. The lengths of convergent and divergent plate boundaries were measured and totaled before and after the plate reorganization (Table 3). Regarding convergent plate boundaries, the process of subduction of oceanic crust which offers relatively low resistance to plate convergence, is distinguished from the process of collision involving continental or transitional (island arc) crust which offers relatively high resistance to plate convergence as a consequence of crustal buoyancy.

Immediately preceding the Early Cenozoic plate reorganization the total lengths of convergent and divergent plate boundaries were nearly equal at 52,000 and $50,000 \mathrm{~km}$, respectively (Table 3 ). Of the $52,000 \mathrm{~km}$ of convergent plate boundaries, only about $2500 \mathrm{~km}$ in the Zagros area is known to have been a collisional boundary; subduction is inferred to have prevailed at the balance of the convergent plate boundaries (Figs. 1,2). In the transition interval during the plate reorganization the length of collisional plate boundaries increased to $28,500 \mathrm{~km}$ (Table 3 ) due to the beginning of the collision of India and Eurasia along an E-W-trending boundary $(5000 \mathrm{~km}$; 55 to 40 m.y. B.P.), collision of the Australian shield with the New Guinea island arc along an E-W-trending boundary $(8000 \mathrm{~km} ; 49$ to 43 m.y. B.P.), collision of the Bahama Banks with the Greater Antilles along an E-W-trending boundary region $(1500 \mathrm{~km}$; post-70 to $43 \mathrm{~m} . \mathrm{y}$. B.P.), and the change from E-W strike slip to N-S collision and compression along an E-W-trending boundary in the Mediterranean region $(11,500 \mathrm{~km} ; 53 \mathrm{~m} . \mathrm{y}$. B.P). Shortly following plate reorganization the collisions in the Australian shield-New Guinea island arc $(8000 \mathrm{~km})$ and the Bahamas Banks-Greater Antilles $(1500 \mathrm{~km})$ stopped, leaving a balance of $19,000 \mathrm{~km}$ of collisions in effect (Table 3). The total length of convergent plate bound- 
TABLE 3

Early Cenozoic plate organization (see Figs. 1, 2)

All convergent plate boundaries (subduction and collision)

\begin{tabular}{lrrr}
\hline & \multicolumn{2}{c}{ Length * (km) } & \\
\cline { 2 - 4 } & before & after & net change \\
\hline $\begin{array}{lrrr}\text { South America and } \\
\quad \text { North America }\end{array}$ & 17,000 & 18,000 & $+1,000$ \\
$\begin{array}{l}\text { Aleutian-Kurile-Japan } \\
\text { Philippine-Ryuku- }\end{array}$ & 8,000 & 8,000 & 0 \\
$\quad$ Marianas-Yap & 0 & 9,000 & $+9,000$ \\
$\begin{array}{l}\text { Zagros-Indus-Indonesia } \\
\text { New Guinea-Tonga }\end{array}$ & 14,000 & 14,000 & 0 \\
Caribbean & 8,000 & 11,500 & $+3,500$ \\
Mediterranean & 5,000 & 2,500 & $-2,500$ \\
$\quad$ Worldwide total & 52,000 & 11,500 & $+11,500$ \\
\hline
\end{tabular}

Convergent plate boundaries: collision

\begin{tabular}{|c|c|c|c|}
\hline & \multicolumn{3}{|c|}{ Length * $(\mathrm{km})$} \\
\hline & before & transition & after \\
\hline Zagros-Indus-Indonesia & 2,500 & 7,500 & 7,500 \\
\hline New Guinea-Tonga & 0 & 8,000 & 0 \\
\hline Caribbean & 0 & 1,500 & 0 \\
\hline Mediterranean & 0 & 11,500 & 11,500 \\
\hline Worldwide total & 2,500 & 28,500 & 19,000 \\
\hline
\end{tabular}

All divergent plate boundaries

\begin{tabular}{|c|c|c|c|}
\hline & \multicolumn{3}{|c|}{ Length $*(\mathrm{~km})$} \\
\hline & before & after & net change \\
\hline East Pacific & 16,000 & 16,000 & 0 \\
\hline $\begin{array}{l}\text { Australia-Antarctic- } \\
\text { Indian }\end{array}$ & 3,000 & 12,000 & $+9,000$ \\
\hline Indonesian & 10,000 & 0 & $-10,000$ \\
\hline Red Sea & 0 & 2,000 & $+2,000$ \\
\hline Atlantic-Arctic & 19,000 & 20,000 & $+1,000$ \\
\hline Tasman & 2,000 & 0 & $-2,000$ \\
\hline Worldwide total & 50,000 & 50,000 & 0 \\
\hline
\end{tabular}

* Measured with estimated $5 \%$ accuracy on $40 \mathrm{~cm}$ diameter globe.

aries including both subduction and collision had increased to $74,500 \mathrm{~km}$, an addition of $22,500 \mathrm{~km}$ over the pre-organizational total, while that of divergent plate boundaries remained at $50,000 \mathrm{~km}$, no change from the pre-reorganizational total.

\section{Conclusions}

A statement by McKenzie and Sclater [64] with reference to the Indian Ocean region helps to elucidate the global observations presented: "Since the momentum of plates can always be neglected, any change in their motion must involve a change in either the driving forces or the resistive forces." The evidence presented clearly supports the interpretation that the plate reorganization from Mesozoic to Cenozoic patterns of plate motion was primarily a response to the global distribution of resistive forces.

The increase in E-W-trending collisional plate boundaries from about 2500 to 28,500 (5-38\% of total length of convergent plate boundaries) during the interval between 55 and 40 m.y. B.P. (Tables 1 , 3 ) produced a corresponding increase in resistance that apparently forced the global plate system to reorganize along lines of less resistance. The reorganization involved reorientation of relative plate motions with large N-S components into large E-W components, continuation of pre-existing E-W sea floor spreading, initiation of new E-W spreading, deceleration of spreading rates, complex antithetic and sequential events limited to certain regions, and obduction of ophiolites. The persistence of about $19,000 \mathrm{~km}$ of collisional plate boundaries subsequent to 40 m.y. B.P. has acted to constrain the global pattern of plate motion established by the Early Cenozoic plate reorganization. The occurrence of global plate reorganizations in Early Mesozoic and Early Cenozoic suggests a plate tectonic basis for the division of the Phanerozoic time scale into eras.

\section{Acknowledgements}

We thank Steven Schamel for guidance in the structural history of the Mediterranean region. We thank C.G.A. Harrison and Walter C. Pitman III for helpful reviews. This research was supported by NOAA. Contribution from NOAA and the University of Miami, Rosenstiel School of Marine and Atmospheric Sciences.

\section{References}

[1] R.S. Dietz and J.C. Holden, Reconstruction of Pangaea: breakup and dispersion of continents, Permian to 
present, J. Geophys. Res. 75 (1970) 4939.

[2] J.E. Van Hinte, A Cretaceous time scale, Am. Assoc. Pet. Geol. Bull. 60 (1976) 498.

[3] W.A. Berggren, Cenozoic chronostratigraphy, planktonic foraminiferal zonation and the radiometric time-scale, Nature 224 (1969) 1072.

[4] J.L. La Brecque, D.V. Kent and S.C. Cande, Revised magnetic polarity time scale for Late Cretaceous and Cenozoic times, Geology 5 (1977) 330.

[5] A. Gansser, Geology of the Himalayas (Interscience, London, 1964) 289.

[6] A. Gansser, The Indian Ocean and the Himalayasgeological interpretation, Eclogae Geol. Helv. (59) 831.

[7] A. Sahni and V. Kumar, Paleogene palaeobiogeography of the Indian subcontinent, Palaeogeogr., Palaeoclimatol., Palaeoecol. 15 (1974) 209.

[8] P. Le Fort, Himalayas: the collided range. Present knowledge of continental arc, Am. J. Sci. 275-A (1975) 1.

[9] P. Molnar and P. Tapponier, The collision between India and Eurasia, Sci. Am. 236 (1977) 30.

[10] J.G. Sclater and R.L. Fisher, Evolution of the East Central Indian Ocean with emphasis on the tectonic setting of the Ninetyeast Ridge, Geol. Soc. Am. Bull. 85 (1974) 683.

[11] B.D. Johnson, C. McA. Powell and J.J. Veevers, Spreading history of the eastern Indian Ocean and Greater India's northward flight from Antarctica and Australia, Geol. Soc. Am. Bull. 87 (1976) 1560.

[12] J.W. Pierce, The origin of the Ninetyeast Ridge and the northward motion of India, based on DSDP paleolatitudes, Doctoral Dissertation, Woods Hole Oceanographic Institution (1977) 283.

[13] W.C. Pitman III, R.L. Larson and E.M. Herron, The Age of the Ocean Basins (Geological Society of America, 1974) 2 maps.

[14] D.E. Hayes and J. Ringis, The early opening of the central Tasman Sea, EOS, Trans. Am. Geophys. Union 53 (1972) 413 (abstract).

[15] J.K. Weissel and D.E. Hayes, Magnetic anomalies in the southeast Indian Ocean; in: Antarctic Oceanology II: The Australian-New Zealand sector, D.E. Hayes, ed., Am. Geophys. Union, Antarctic Res. Ser. 19 (1972) 165.

[16] M.E. Brookfield, The emplacement of giant ophiolite nappes, I. Mesozoic-Cenozoic examples, Tectonophysics 37 (1977) 247.

[17] P. Molnar and P. Tapponnier, Cenozoic tectonics of Asia: effects of a continental collision, Science 189 (1975) 419.

[18] W.C. Pitman III, E.M. Herron and J.R. Heirtzler, Magnetic anomalies in the Pacific and sea floor spreading, J. Geophys. Res. 73 (1968) 2069.

[19] J.R. Heirtzler, G.O. Dickson, E.M. Herron, W.C. Pitman III and $X$. Le Pichon, Marine magnetic anomalies, geomagnetic field reversals, and motions of the ocean floor and continents, J. Geophys. Res. 73 (1968) 2119.

[20] E.M. Herron, Magnetic lineations in the extreme southeast Pacific and their bearing on the evolution of the
Scotia Arc and Pategonia, Geol. Soc. Am., Abstr. Progr, 6 (1974) 791.

[21] P.J. Coney, Cordilleran tectonic transitions and motion of the North American plate, Nature 233 (1971) 462.

[22] H.W. Menard and T. Atwater, Changes in direction of sea floor spreading, Nature 219 (1968) 463.

[23] S. Uyeda and Z. Ben-Arraham, Origin and development of the Philippine Sea, Nature Phys. Sci. 240 (1972) 176

[24] T.W.C. Hilde, S. Uyeda and L. Kroenke, Evolution of the western Pacific and its margins, in: Present State of Plate Tectonics, J. Bonnin and R.S. Dietz, eds. Tectonophysics 38 (1977) 145.

[25] S. Uyeda, Some basic problems in the trench-arc-back arc system, in: Island Arcs, Deep Sea Trenches and Back-Arc Basins, M. Talwani and W.C. Pitman III, eds., Am. Geophys. Union, Maurice Ewing Ser. 1 (1977) 1.

[26] D.A. Clague, G.B. Dalry mple and R. Moberly, Petrography and $\mathrm{K}$-At ages of dredged volcanic rocks from the western Hawaiian Ridge and the southern Emperor Seamount, Geol. Soc. Am. Bull. 86 (1975) 991.

[27] W.C. Pitman III and M. Talwani, Sea-floor spreading in the North Atlantic, Geol. Soc. Am. Bull. 83 (1972) 619.

[28] E.M. Herron, J.F. Dewey and W.C. Pitman III, Plate tectonics model for the evolution of the Arctic, Geology 2 (1974) 377.

[29] P.R, Vogt, N.A. Ostenso and G.L. Johnson, Magnetic and bathymetric data bearing in sea-floor spreading north of Iceland, J. Geophys. Res. 75 (1970) 903.

[30] M. Mayhew, C.L. Drake and J.F. Nafe, Marine geophysical measurements on the continental margins of Labrador Sea, Can. J. Earth Sci. 7 (1970) 199.

[31] X. Le Pichon, R.D. Hyndman and G. Pautot, Geophysical study of the opening of the Labrador Sea. J. Geophys. Res. 76 (1971) 4724.

[32] P.R. Vogt, O.E. Avery, W.J. Morgan, G.L. Johnson, E.D. Schneider and R.H. Higgs, Morphology, magnetic anomalies and evolution of the northeast Atlantic and Labrador Sea, 3. Evolution, EOS, Trans. Am. Geophys. Union 50 (1969) 184 (abstract).

[33] E.M. Herron and M. Talwani, Magnetic anomalies on the Reykjanes Ridge, Nature 238 (1972) 390.

[34] R.K. Lattimore, P.A. Rona and O.E. DeWald, Magnetic anomaly sequence in the Central North Atlantic. J. Geophys. Res. 79 (1974) 1207.

[35] P.D. Rabinowitz and G.M. Purdy, The Kane fracture zone in the western Central North Atlantic Ocean, Earth Planet. Sci. Lett. 33 (1976) 21.

[36] G.O. Dickson, W.C. Pitman III and J.R. Heirtzler, Magnetic anomalies in the South Atlantic and ocean floor spreading, J. Geophys. Res. 73 (1968) 2087.

[37] A.E. Maxwell, Initial Reports of the Deep Sea Drilling Project III, U.S. Government Printing Office, Washington, D.C. (1970) 806

[38] J.W. Ladd, G.P. Dickson and W.C. Pitman III, The age of the South Atlantic, in: The Ocean Basins and Margins, 1. The South Atlantic, A.E.M. Nairn and F.G. Stehli. 
eds. (Plenum Press, New York, N.Y., 1973) 555.

[39] B.T. Malfait and M.G. Dinkelman, Circum-Caribbean tectonic and igneous activity and the evolution of the Caribbean plate, Geol. Soc. Am. Bull. 83 (1972) 251.

[40] R. Weyl, Die Geologie der Antillen (Gebr. Borntraeger, Berlin, 1966) 410.

[41] A.A. Meyerhoff and C.W. Hatten, Diapiric structures in central Cuba, Am. Assoc. Pet. Geol. Mem. 8 (1968) 315.

[42] P.H. Mattson, Middle Cretaceous nappe structures in Puerto Rican ophiolites and their relation to the tectonic history of the Greater Antilles, Geol. Soc. Am. Bull. 84 (1973) 21.

[43] W.H. Monroe, The age of the Puerto Rico Trench, Geol. Soc. Am. Bull. 79 (1978) 487.

[44] K.M. Khudoley and A.A. Meyerhoff, Paleogeography and geological history of the Greater Antilles, Geol. Soc. Am. Mem. 129 (1971) 199.

[45] B.E. Tucholke and J.I. Ewing, Bathymetry and sedimentary structure of the Greater Antilles outer ridge and vicinity, Geol. Soc. Am. Bull. 85 (1974) 1789.

[46] F. Nagle, Geology of the Puerto Plata area, Dominican Republic, relative to the Puerto Rico Trench, in: Transactions, 5th Caribbean Geological Conference, St. Thomas, V.I., P.H. Mattson, ed., Queens College Geol. Bull. 5 (1971) 79.

[47] T.L. Holcombe, P.R. Vogt, J.E. Matthews and R.R. Murchison, Evidence for sea floor spreading in the Cayman Trough, Earth Planet. Sci. Lett. 20 (1973) 357.

[48] B.C. Heezen, M.R. Perfit and M. Dreyfus, The Cayman Ridge, Geol. Soc. Am., Abstr. Progr. 5 (1973) 663.

[49] J.F. Dewey, W.C. Pitman III, W.B.F. Ryan and J. Bonnin, Plate tectonics and the evolution of the Alpine system, Geol. Soc. Am. Bull. 84 (1973) 3137.

[50] G. Boillot and R. Capdevila, The Pyrenees: subduction and collision?, Earth Planet. Sci. Lett. 35 (1977) 151.

[51] K.J. Hsü and S.O. Schlanger, Ultrahelvetic flysch sedimentation and deformation related to plate tectonics,
Geol. Soc. Am. Bull. 82 (1971) 1207.

[52] R. Trümpy, Penninic-Austroalpine boundary in the Swiss Alps: a presumed former continental margin and its problems, Am. J. Sci. 275-A (1975) 209.

[53] V.J. Dietrich, Evolution of the Eastern Alps: a plate tectonics working hypothesis, Geology 4 (1976) 147.

[54] R. Lafitte, Les plissements post-nummalitiques dans l'A tlas Saharien, Bull. Soc. Geol. Fr. 5 (1939) 135.

[55] Société Chérifienne des Pétroles, Le Bassin du SudOuest Marocain, in: Sedimentary Basins of the African Coasts, 1. Atlantic Coast, D. Reyre, ed. (Assoc. African Geol. Surveys, Paris, 1966) 5.

[56] R.W. Girdler and P. Styles, Two stage Red Sea floor spreading, Nature 247 (1974) 7.

[57] H.L. Davies and I.E. Smith, Geology of Eastern Papua, Geol. Soc. Am. Bull. 82 (1971) 3299.

[58] J. Avias, Overthrust structure of the main ultrabasic New Caledonian Massives, Tectonophysics 4 (1967) 531.

[59] J.J. Guillon and P. Rothier, Les stades d'evolution et de mise en place des Massifs ultramafiques de Nouvelle Calédonie, Bull. B.R.G.M. 2 (1971) 5.

[60] R.G. Coleman and W.P. Irwin, Ophiolites and ancient continental margins in: The Geology of Continental Margins, C.A. Burk and C.L. Drake, eds. (SpringerVerlag, New York, N.Y., 1974) 921.

[61] R.G. Tysdale, J.E. Case, G.R. Winkler and S.H.B. Clark, Sheeted dikes, gabbro, and pillow basalt in flysch of coastal southern Alaska, Geology 5 (1977) 377.

[62] A. Gansser, Asseralpine ophiolithprobleme, Eclogae Geol. Helv. 52 (1959) 659.

[63] W.G. Ernst, Interpretative synthesis of metamorphism in the Alps, Geol. Soc. Am. Bull. 84 (1973) 2053.

[64] D.P. McKenzie and J.G. Sclater, The evolution of the Indian Ocean since the Late Cretaceous, Geophys. R. Astron. Soc. J. 25 (1971) 437.

[65] J.C. Briden, G.E. Drewry and A.G. Smith, Phanerozoic equal-area world maps, J. Geol. 82 (1974) 555. 